\title{
The Effectiveness of Corporate Governance in Constraining Earnings Management in Pakistan
}

\author{
Aysha S. Latif* and Fahad Abdullah ${ }^{* *}$
}

\begin{abstract}
Although firms' annual reports are supposed to provide an unbiased and accurate picture of their financial position, managers may be induced to engage in earnings management in order to circumvent expectations. Such incentives can take the shape of stock prices, management incentives, or debt covenants. The purpose of this study is to investigate the effectiveness of three attributes of corporate governance in constraining earnings management practices. These include board characteristics, audit committee characteristics, and ownership structure. Based on a sample of 120 nonfinancial firms listed on the Karachi Stock Exchange during 2003-12, we find that audit committee independence is negatively associated with earnings management, while CEO duality and institutional shareholding is positively associated with earnings management. Moreover, the effectiveness of governance mechanisms in constraining earnings management practices differs across high-and low-growth firms.
\end{abstract}

Keywords: Earnings management, financial statements, corporate governance, board characteristics, audit committee characteristics, ownership structure, Pakistan.

\section{JEL classification: G34.}

\section{Introduction}

The International Financial Reporting Standards (IFRS) allow firm managers greater flexibility in choosing from among alternative accounting treatments. These choices can have different effects on a firm's reported income. Islam, Ali, and Ahmad (2011) argue that managers tend to prefer accounting choices that benefit them economically. The likelihood of this opportunistic behavior rises in the presence of weak governance structures, eventually causing the quality of reported earnings to deteriorate and reducing investors' confidence in financial reports (González \& García-Meca, 2014). This opportunistic behavior,

\footnotetext{
* Lecturer, University of Peshawar.

** Assistant professor, Institute of Management Sciences, Peshawar.
} 
known as earnings management, entails the creative use of accounting techniques in such a way that the financial reports produced give an overly positive picture of firms' business activities and financial position. Earnings management can include changes in the estimated amount of assets impaired, the volume of bad debts written off, the amount of inventory recorded, the estimated useful life of long-term assets, and estimated post-employment benefits and warranty costs (McKee, 2005).

Prior studies suggest that good governance is crucial in monitoring managerial activities because it helps reduce agency costs by aligning the interests of the management and owners. Several studies have examined the role of corporate governance in earnings management and found that good governance can effectively constrain managers from being involved in earnings management practices (see Jiang, Lee, \& Anandarajan, 2008; Dimitropoulos \& Asteriou, 2010; Alzoubi \& Selamat, 2012; González \& García-Meca, 2014).

This study is motivated by two considerations. First, investment or capital is crucial for an emerging economy such as Pakistan where the domestic saving rate is only 13.5 percent of gross domestic product: this is insufficient to ensure economic growth of at least 7-8 percent a year. Second, the country's investment climate is not attractive, given that firms involved in earnings management are liable to spread false information in the market. This induces investors to make sale or purchase decisions that lead to losses, ultimately eroding their confidence. In order to attract more capital and enhance investor confidence, companies need to provide an attractive investment climate and good governance, increase overall transparency, and reduce information asymmetry.

In this context, the study's first objective is to examine the effectiveness of corporate governance mechanisms in constraining earnings management. We do so by looking at eight such mechanisms grouped into three categories: (i) board characteristics, (ii) audit committee characteristics, and (iii) ownership structure.

Our second objective is to investigate whether the role of corporate governance in constraining earnings management differs between high- and low-growth firms. This builds on the argument presented by Bowen, Rajgopal, and Venkatachalam (2008) that the market severely penalizes highgrowth firms for negative earnings surprises. This suggests there is a strong incentive for high-growth firms to meet earnings benchmarks, perhaps to maintain their capital or avoid a higher cost of capital. Moreover, Cohen, 
Krishnamoorthy, and Wright (2004) indicate that the impact of governance mechanisms differs with a firm's growth opportunities.

The study contributes to the existing literature in the following ways. First, it extends the very limited research on the relationship between corporate governance and earnings management in Pakistan by providing a detailed and comprehensive picture of this association. Second, it analyzes the empirical evidence on growth differences in this relationship, which has not yet been done.

Section 2 provides a comprehensive literature review, on the basis of which we formulate a series of hypotheses. Section 3 describes the variables used as well as the sample and data sources employed. It also presents the study's methodology and specifies the econometric model to be tested. Section 4 discusses the empirical findings and Section 5 concludes the study.

\section{Literature Review}

This section provides a literature review for each of the variables used in the study.

\subsection{Earnings Management}

Healy and Wahlen (1999) define earnings management as the use of managerial judgment in structuring transactions to alter financial reports either to misinform stakeholders with respect to the firm's performance or to reap the benefit of a contractual outcome that is dependent on accounting numbers. Managers thus estimate future economic events at their discretion and these are reflected in firms' financial reports. Such events can include salvage value and the expected life of long-term assets, deferred taxes, asset impairment, losses from bad debts, and post-employment benefits.

Managerial discretion also influences the choice of acceptable accounting methods for inventory costing, such as last-in-first-out (LIFO), first-in-first-out (FIFO), and average cost. These can have a significant impact on accounting outcomes in different economic conditions (Zhang, Shi, Gao, \& Wang, 2014) and on recording transactions such as accelerated depreciation or the straight-line method. Waweru and Riro (2013) argue that managers also use their discretion in working capital management such as in receivables policies, the timing of inventory purchases, and inventory levels. All these affect net revenues and cost allocations. 
In earnings management, accounting choices are made to reflect either increased or decreased income. For example, in certain instances, stockholders and managers may agree that earnings management is desirable and choose to apply income-decreasing accounting choices to avoid incurring regulatory or political costs (Peasnell, Pope, \& Young, 2005). On the other hand, when the interests of shareholders and managers diverge, this gives rise to moral hazard. Almilia (2009) notes that agency theory is an important construct in understanding financial reporting incentives. Agency theory holds that, in the presence of information asymmetries, managers will choose to make a set of decisions that maximize their usefulness.

\subsection{Corporate Governance and Earnings Management}

Broadly, corporate governance refers to the processes, rules, or laws under which a company is directed. These are intended to ensure fairness, transparency, and accountability in its relationship with all stakeholders. The concept of corporate governance assumed considerable importance following a wave of high-profile corporate corruption scandals (Standard and Poor's, 2003), most of which were traced to earnings management.

The theories put forward with respect to corporate governance include agency theory, stakeholder theory, and stewardship theory. Of these, agency theory has been the most influential: it states that managers pursue self-interested strategies and will not act to maximize shareholders' wealth unless an appropriate governance structure is implemented to safeguard the latter's interests (Jensen \& Meckling, 1976). Codes of corporate governance support the concept of independence and a balance of power in the boardroom; they seek to protect shareholders' rights and recognize the importance of transparency and disclosure. Jiang et al. (2008) argue that corporate governance is critical to better financial reporting, and suggest that higher levels of corporate governance are associated with lower discretionary accruals (i.e., earnings management) and higher-quality earnings.

\subsection{Board Characteristics}

In any firm, the board of directors is the main decision-making body and its composition has an important impact on the quality of reported earnings. Dimitropoulos and Asteriou (2010) show that the informativeness of annual accounting earnings is positively related to the 
number of outside directors serving on the board. Alzoubi and Selamat (2012) observe that a board comprising primarily external directors is better placed to control and monitor management. This reduces the agency problem inherent in any firm and improves financial reporting quality. Based on the literature, our first hypothesis (H1) is that board independence is negatively related to earnings management.

Jensen (1993) argues that chief executive officer (CEO) dualitythat is, when the CEO also serves as board chairperson-enables a more flexible environment for the firm's management, allowing the CEO to control what information is available to other directors. Davidson, Jiraporn, Kim, and Nemec (2004) conclude that CEO duality gives the CEO greater control over the perception created by the firm's financial reports. This concentrates more power in the CEO's position and allows greater managerial discretion. Thus, our second hypothesis $(\mathrm{H} 2)$ is that CEO duality is positively related to earnings management.

Additionally, the size of the board significantly influences its ability to monitor. Jensen (1993) argues that a small board can monitor the CEO's actions more effectively because a larger board might be more likely to concern itself with etiquette at the expense of monitoring. Abbott, Parker, and Peters (2004) find that small boards communicate more effectively and with fewer misunderstandings. Small boards are also more sensitive to issues affecting investor confidence, particularly in financial reporting and, therefore, less likely to engage in earnings management. Thus, our third hypothesis (H3) is that the size of the board is positively associated with earnings management.

Board meetings provide an opportunity to discuss issues related to the firm. Chen, Firth, Gao, and Rui (2006) observe that the potential for fraud is reduced when the board meets frequently because this allows the directors to identify and resolve any potential problems. Based on this, we expect an inverse relationship between board meetings and earnings management. Our fourth hypothesis ( $\mathrm{H} 4)$ is that the frequency of board meetings is negatively related to earnings management.

\subsection{Audit Committee Characteristics}

Essentially, audit committees must remain independent to be able to carry out their oversight-related functions. Klein (2002) finds that the independence of an audit committee is negatively related to earnings management. Alzoubi and Selamat (2012) and Mansor, Che-Ahmad, 
Ahmad-Zaluki, and Osman (2013) conclude that larger audit committees with a greater degree of independence perform better as oversight bodies. Based on these studies, our fifth and sixth hypotheses are as follows:

- H5: Audit committee size is negatively related to earnings management.

- H6: The independence of the audit committee is negatively related to earnings management.

\subsection{Ownership Structure}

Given that ownership structure is an effective governance mechanism, one of our aims is to examine the impact of insider and institutional shareholding on earnings management. Cornett, Marcus, Saunders, and Tehranian (2006) argue that insider shareholders may choose to manipulate earnings to improve the firm's perceived performance and to increase their personal wealth. This may be to attract investors and to unload shareholding. Beneish and Vargus (2002) point out that insider sales of shares increase in periods of inflated earnings. However, when managers want to retain the firm's ownership stake, they become more conscious of its true performance. Managers may also practice earnings management when given the incentive of political or regulatory costs. Klein (2002), for instance, argues that managers in taxoriented reporting regimes are motivated to manipulate earnings. The study's seventh hypothesis (H7) is that insider ownership is positively associated with earnings management.

Hartzell and Starks (2003) find that institutional investors are able to restrain management from self-serving activities, which suggests that the former should be negatively related to earnings management. However, another body of knowledge suggests that institutional investors are "transient investors" who focus on short-term earnings and pressure the management into delivering higher consistent earnings (Bushee, 1998). Cornett et al. (2006) also show that, to meet these earnings goals, the management may become involved in earnings manipulations. Based on this discussion, our eighth hypothesis (H8) is that institutional ownership is positively related to earnings management.

\section{Methodology}

This section describes the sample and variables used, and presents the study's methodology. 


\subsection{Sample and Data Sources}

The sample comprises 120 nonfinancial firms listed on the Karachi Stock Exchange (KSE) from 2003 to 2012. Only those firms were included in the sample for which at least three years' data were available. The data on ownership structure were taken from the pattern of shareholding described in the firms' financial reports. The data on board size, audit committee size, and CEO duality were obtained from the firms' profiles. Details of board independence and audit committee members were obtained from each firm's statement of compliance. Data on board meetings were taken from the director's report in each case. Finally, share prices were obtained from the KSE website.

\subsection{Earnings Management}

The notion behind accruals accounting is that there is a difference between cost and expenditure versus benefits and revenues. As a result, net income can be seen as an adjustment of the operational cash flow for transitory components; these adjustments are called accruals (Abed, AlAttar, \& Suwaidan, 2012). Dechow, Sloan, and Sweeney (1996) argue that accruals are more open to discretion than cash flows. Previous studies have often used discretionary accruals (the difference between total accruals and nondiscretionary accruals) as a proxy for earnings management (see Peasnell et al., 2005; Islam et al., 2011).

\subsection{Measurement of Total Accruals}

Total accruals can be measured using either the cash flow approach or the balance sheet approach. Hribar and Collins (2002) show that, in some circumstances, the latter is inferior to the cash flow approach. Having weighed both, however, most researchers prefer to use the cash flow approach and this study follows suit. Thus, total accruals are measured as the difference between net income (NI) and the cash flow from operations (CFO):

$$
T A_{t}=N I_{t}-C F O_{t}
$$

where, in year $t, T A_{t}$ represents total accruals, $N I_{t}$ represents net income, and $C F O_{t}$ represents the cash flow from operations. 


\subsection{Measurement of Discretionary Accruals}

Discretionary accruals are computed as the difference between total accruals and nondiscretionary accruals:

Total accruals $\left(T A_{i t}\right)=$ nondiscretionary accruals $\left(N D A_{i t}\right)+$ discretionary accruals $\left(D A_{i t}\right)$

The original Jones model developed in 1991 estimates nondiscretionary accruals using the following equation:

$\frac{T A_{i t}}{\text { Assets }_{i t-1}}=\alpha_{0}\left(\frac{1}{\text { Asset }_{i t-1}}\right)+\beta_{1}\left(\frac{\Delta R E V_{i t}}{\text { Asset }_{i t-1}}\right)+\beta_{2}\left(\frac{P P E_{i t}}{\text { Asset }_{i t-1}}\right)+\epsilon_{i t}$

The subscript it represents firm $i$ and year $t . \triangle R E V$ is the change in revenue and PPE represents property, plant, and equipment.

Dechow et al. (1996) compare various models used to measure accruals and develop a modified form of the Jones model, which can better detect accruals management. The modified Jones model adjusts the change in revenue with the change in receivables in the original model in order to reduce the measurement error of accruals when a firm's management uses its discretion in revenues. Thus, the modified model estimates nondiscretionary accruals as follows:

$\frac{T A_{i t}}{\operatorname{Assets}_{i t-1}}=\alpha_{0}\left(\frac{1}{\text { Asset }_{i t-1}}\right)+\beta_{1}\left(\frac{\Delta R E V_{i t}-\Delta R E C_{i t}}{\text { Asset }_{i t-1}}\right)+\beta_{2}\left(\frac{P P E_{i t}}{\text { Asset }_{i t-1}}\right)+\epsilon_{i t}$

where $\triangle R E C$ is the change in receivables.

McNichols (2000) argues that firms with a higher rate of growth tend to have more accruals. Thus, to capture the growth factor, the bookto-market (BM) ratio is incorporated in the modified Jones model to yield the augmented Jones model (Cohen, Dey, \& Lys, 2004) given below:

$\frac{T A_{i t}}{\text { Assets }_{i t-1}}=\alpha_{0}\left(\frac{1}{\beta_{3} C \text { Aset }_{i t-1}}\right)+\beta_{1}\left(\frac{\Delta R E V_{i t}-\triangle R E C_{i t}}{\text { Asset }_{i t-1}}\right)+\beta_{2}\left(\frac{P P E_{i t}}{\text { Asset }_{i t-1}}\right)+$ $\beta_{3}$ CFROA $_{i t}+\beta_{4} B M_{i t}+\epsilon_{i t}$

where

$\frac{N D A_{i t}}{\text { Assets }_{i t-1}}=\hat{\alpha}_{0}\left(\frac{1}{\text { Assets }_{i t-1}}\right)+\beta_{1}^{\wedge}\left(\frac{\Delta R E V_{i t}-\Delta R E C_{i t}}{\text { Asset }_{i t-1}}\right)+\beta_{2}^{\wedge}\left(\frac{P P E_{i t}}{\text { Assets }_{i t-1}}\right)+$
$\beta_{3}^{\wedge}$ CFROA $_{i t}+\beta_{4}^{\wedge} B M_{i t}$ 
Discretionary accruals can be written as:

$\frac{D A_{i t}}{\text { Assets }_{i t-1}}=\frac{T A_{i t}}{\text { Assets }_{i t-1}}-\left[\hat{\alpha}_{0}\left(\frac{1}{\text { Assets }_{i t-1}}\right)+\beta^{\wedge}\left(\frac{\Delta R E V_{i t}-\Delta R E C_{i t}}{\text { Asset }_{i t-1}}\right)+\right.$
$\left.\beta_{2}^{\wedge}\left(\frac{P P E_{i t}}{\text { Assets }_{i t-1}}\right)+\beta_{3}^{\wedge} C F R O A_{i t}+\beta_{4}^{\wedge} B M_{i t}\right]$

CFROA is the cash flow return on assets and is measured as income before interest and taxes plus depreciation divided by total assets. $\mathrm{BM}$ is measured as the book value of equity divided by the market value of equity.

Other studies have used cross-sectional versions of the Jones and modified Jones models to estimate discretionary accruals (see DeFond \& Jiambalvo, 1994; Bartov, Gul, \& Tsui, 2000). Bartov et al. (2000), for instance, compare these cross-sectional versions with their time-series counterparts and find that the former are better able to detect earnings management. Accordingly, we have also estimated cross-sectional models to detect discretionary accruals.

\subsection{Model Specification for Governance Mechanisms and Earnings Management}

The study examines the effect of eight corporate governance mechanisms in constraining earnings management, where the control independent variables include leverage, CEO compensation, and firm size. We develop the following regression model to determine the relationship between governance mechanisms and earnings management:

$$
\begin{aligned}
& \frac{D A_{i t}}{\text { Assets }_{i t-1}}=\alpha_{0}+\beta_{1} \text { IBOARD }_{i t}+\beta_{2} \text { CEO }_{i t}+\beta_{3} S B O A R D_{i t}+\beta_{4} \text { MBOARD }_{i t}+ \\
& \beta_{5} S A C_{i t}+\beta_{6} I_{\text {IA }}+\beta_{7} \text { POI }_{i t}+\beta_{8} \text { POINST }_{i t}+\beta_{9} L E V_{i t}+\beta_{10} \text { COMP }_{i t}+ \\
& \beta_{11} \text { LASSET }_{i t}+\epsilon_{i t}
\end{aligned}
$$

IBOARD is board independence, measured as the percentage of independent directors on the board. CEO duality is a dummy variable that takes the value of 1 when the CEO is also the board chairperson and 0 otherwise. SBOARD is the size of the board, measured as the number of board directors. MBOARD is the natural log of the number of board meetings held during the year. SAC represents the number of members on the audit committee. IAC represents audit committee independence, measured as the percentage of nonexecutive directors on the committee. POI is insider ownership, measured as the percentage of equity owned by the firm's directors and managers. POINST is institutional ownership, 
measured as the percentage of equity owned by institutional investors. LEV is leverage, measured as the book value of debt divided by the firm's market value (equal to the sum of long-term debt, short-term debt, and the market value of equity). CEO compensation is denoted by COMP, which is the natural log of the amount of compensation paid to the CEO during the year. Finally, the size of the firm (LASSET) is measured by taking the natural log of its total assets.

\section{Results and Discussion}

Table 1 gives the estimation results for the cross-sectional versions of the Jones model, modified Jones model, and augmented Jones model. The coefficients in each case are significant and have the same sign, but the explanatory power of the models is different. The augmented Jones model yields an R-squared value of 24.74 percent, which is higher than that of the other two models. Based on this, we opt to use the augmented Jones model, and measure nondiscretionary and discretionary accruals using equations 3.1 and 3.2.

Table 2 shows that the mean of discretionary accruals is almost 0 . This is because, at some point, discretionary accruals are reversed and assume an average value of 0 in the long run. The average proportion of independent board members is 0.22 with a minimum value of 0 . The sample firms have between 14 (maximum) and six (minimum) members. Board and executive members own, on average, 18 percent of total equity and the maximum shareholding by insiders is 98 percent. Institutional shareholdings range from 0 to 97 percent. On average, the proportion of outside members on the audit committees is 0.8 . 
Table 1: Cross-sectional estimates of Jones, modified Jones, and augmented Jones models

\begin{tabular}{|c|c|c|c|c|c|}
\hline & & & & \multicolumn{2}{|c|}{ Dependent variable $=\frac{T A_{i t}}{A S S E T S_{i t-}}$} \\
\hline \multicolumn{6}{|c|}{ t-statistics } \\
\hline \multicolumn{2}{|c|}{ Jones model (1) } & \multicolumn{2}{|c|}{ Modified Jones model (2) } & \multicolumn{2}{|c|}{ Augmented Jones model (3) } \\
\hline$\Delta R E V_{i t}$ & $0.0945^{* * *}$ & $\Delta R E V_{i t}-\triangle R E C_{i t}$ & $0.0778^{* * *}$ & $\Delta R E V_{i t}-\triangle R E C_{i t}$ & $0.0264^{*}$ \\
\hline$\overline{\text { Assets }_{i t-1}}$ & $(6.3283)$ & Assets $_{i t-1}$ & $(5.0833)$ & $\overline{\text { Assets }_{i t-1}}$ & $(1.8579)$ \\
\hline$P P E_{i t}$ & $-0.0591^{* * *}$ & $P P E_{i t}$ & $-0.0595^{* * *}$ & $P P E_{i t}$ & $-0.0417^{* *}$ \\
\hline$\overline{\text { Assets }_{i t-1}}$ & $(-3.1883)$ & $\overline{\text { Assets }_{i t-1}}$ & $(-3.1789)$ & $\overline{\text { Assets }_{i t-1}}$ & $(-2.4572)$ \\
\hline- & - & - & - & CFROA & $\begin{array}{l}0.6235^{* * *} \\
(13.5121)\end{array}$ \\
\hline- & - & - & - & BM & $\begin{array}{l}0.0054^{*} \\
(1.8907)\end{array}$ \\
\hline Constant & $\begin{array}{l}0.0280^{* *} \\
(2.3869)\end{array}$ & Constant & $\begin{array}{l}0.0326^{* * *} \\
(2.7654)\end{array}$ & Constant & $\begin{array}{l}-0.0344^{* * *} \\
(-2.8564)\end{array}$ \\
\hline R-squared & 0.0678 & R-squared & 0.0495 & R-squared & 0.2474 \\
\hline F-test & $25.33^{* * *}$ & F-test & $18.12^{* * *}$ & F-test & $57.05^{* * *}$ \\
\hline
\end{tabular}

Note: ${ }^{* * *},{ }^{* *}$ and ${ }^{*}=$ significant at 1 percent, 5 percent, and 10 percent level, respectively. Source: Authors' calculations.

Table 2: Descriptive statistics

\begin{tabular}{|c|c|c|c|c|c|c|c|c|c|c|c|}
\hline & $\overleftrightarrow{\circ}$ & 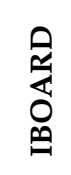 & 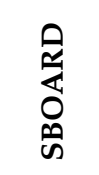 & 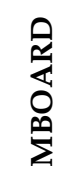 & $\underset{\omega}{u}$ & U & อี & $\begin{array}{l}\text { 年 } \\
Z \\
0 \\
0\end{array}$ & 斑 & $\sum_{0}^{j}$ & 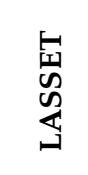 \\
\hline Mean & 0.00 & 0.22 & 8.27 & 1.65 & 3.41 & 0.79 & 0.18 & 0.23 & 0.48 & 8.03 & 15.31 \\
\hline Stan & 0.01 & 0.01 & 0.06 & 0.01 & 0.03 & 0.01 & 0.01 & 0.01 & 0.01 & 0.10 & 0.06 \\
\hline Medi & -0.01 & 0.13 & 8.00 & 1.61 & 3.00 & 0.75 & 0.06 & 0.18 & 0.48 & 8.80 & 15.42 \\
\hline Range & 1.63 & 0.93 & 8.00 & 3.17 & 4.00 & 1.00 & 0.98 & 0.97 & 0.99 & 12.24 & 10.36 \\
\hline Minimı & -0.86 & 0.00 & 6.00 & 0.39 & 2.00 & 0.00 & 0.00 & 0.00 & 0.00 & 0.00 & 8.79 \\
\hline Maximum & 0.78 & 0.93 & 14.00 & 3.56 & 6.00 & 1.00 & 0.98 & 0.97 & 0.99 & 12.24 & 19.15 \\
\hline
\end{tabular}

Source: Authors' calculations.

The correlation matrix presented in Table 3 shows that discretionary accruals are negatively correlated with the independence of the audit committee and board meetings. Insider shareholding and board independence are weakly correlated with discretionary accruals. Discretionary accruals are positively correlated with CEO duality, institutional shareholding, and CEO compensation. Board independence is positively correlated with board and firm size, indicating that larger firms 
need more members on their board and usually assign these additional seats to outside members. A positive correlation exists between firm size and the size of the audit committee. There is a negative correlation between audit committee independence and insider ownership.

Table 3: Correlation analysis

\begin{tabular}{|c|c|c|c|c|c|c|c|c|c|c|c|c|}
\hline Variable & 台 & 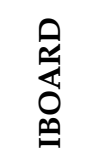 & O & $\begin{array}{l}\text { 令 } \\
\text { ô } \\
\text { ô }\end{array}$ & 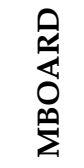 & $\underset{\omega}{u}$ & $\underset{\unlhd}{U}$ & Ö & $\begin{array}{l}\text { 旨 } \\
\mathbf{Z} \\
0 \\
0\end{array}$ & 离 & $\sum_{0}^{b}$ & 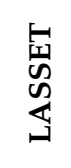 \\
\hline$\overline{\mathrm{DA}}$ & 1.00 & & & & & & & & & & & \\
\hline IBOARD & -0.01 & 1.00 & & & & & & & & & & \\
\hline CEO & 0.19 & -0.03 & 1.00 & & & & & & & & & \\
\hline SBOARD & -0.01 & 0.20 & -0.26 & 1.00 & & & & & & & & \\
\hline MBOARD & -0.12 & -0.01 & -0.08 & 0.01 & 1.00 & & & & & & & \\
\hline SAC & 0.03 & 0.21 & -0.18 & 0.44 & 0.02 & 1.00 & & & & & & \\
\hline IAC & -0.16 & 0.13 & -0.22 & 0.24 & -0.02 & 0.12 & 1.00 & & & & & \\
\hline POI & -0.04 & -0.20 & 0.20 & -0.21 & -0.02 & -0.20 & -0.20 & 1.00 & & & & \\
\hline POINST & 0.17 & 0.18 & 0.11 & 0.06 & -0.09 & 0.08 & 0.01 & -0.26 & 1.00 & & & \\
\hline LEV & 0.00 & -0.12 & 0.16 & -0.15 & -0.04 & -0.17 & -0.05 & 0.23 & -0.14 & 1.00 & & \\
\hline COMP & 0.11 & 0.09 & -0.13 & 0.27 & -0.03 & 0.18 & -0.01 & -0.25 & 0.04 & -0.23 & 1.00 & \\
\hline LASSET & -0.12 & 0.11 & -0.20 & 0.32 & 0.32 & 0.35 & 0.29 & -0.15 & 0.01 & -0.15 & 0.25 & 1.00 \\
\hline
\end{tabular}

Source: Authors' calculations.

Table 4 gives the full sample regression results. We have used panel data regression to test our hypotheses. In column 1, the dependent variable (discretionary accruals) is regressed on all the independent and control variables. In columns 2, 3, and 4, discretionary accruals are regressed on the attributes categorized under board characteristics, audit committee characteristics, and ownership structure, respectively.

Although we would expect board independence to be negatively associated with earnings management, our results indicate no significant relationship between board independence and discretionary accruals. We therefore reject the null hypothesis in this case. The second hypothesis holds because CEO duality is positively related to discretionary accruals. The concentration of power in one position renders the CEO's monitoring role less effective because the management perceives this as having more room to maneuver.

Board size and the frequency of board meetings indicate how active a role the board can play in reducing earnings management. Our 
results, however, show that neither variable has a significant impact on the use of discretionary accruals. Accordingly, we reject the third and fourth hypotheses. We would expect the size of the audit committee to be negatively related to earnings management, assuming that a larger committee is better able to ensure the quality and integrity of reported earnings. However, the results do not indicate a significant relationship between audit committee size and earnings management, leading us to reject the fifth hypothesis.

\section{Table 4: Full sample regression estimates}

\begin{tabular}{lcccc}
\hline & \multicolumn{4}{c}{ Dependent variable $=$ discretionary accruals } \\
\cline { 2 - 5 } Variable & $\mathbf{( 1 )}$ & $\mathbf{( 2 )}$ & $\mathbf{( 3 )}$ & $\mathbf{( 4 )}$ \\
\hline IBOARD (board & -0.0215 & -0.0119 & - & - \\
independence) & $(-1.10)$ & $(-0.61)$ & & \\
CEO (CEO duality) & $0.0435^{* * *}$ & $0.0487^{* * *}$ & - & - \\
SBOARD (board size) & $(3.3 .4)$ & $(3.74)$ & & - \\
& 0.0052 & 0.0062 & - & - \\
MBOARD (board meetings) & $(1.33)$ & $(1.63)$ & & - \\
& -0.0176 & -0.0211 & - & - \\
SAC (size of audit & $(-1.16)$ & $(-1.37)$ & & - \\
committee) & 0.0048 & - & 0.0074 & - \\
IAC (audit committee & $(0.59)$ & & $(0.94)$ & \\
independence) & $-0.0635^{* * *}$ & - & $-0.0736^{* * *}$ & - \\
POI (insider shareholding) & $-2.74)$ & & $(-3.15)$ & -0.0233 \\
& $-0.0462^{*}$ & - & - & $(-0.88)$ \\
POINST (institutional & $(-1.74)$ & & & $0.0860^{* * *}$ \\
shareholding) & $0.0715^{* * *}$ & - & - & $(3.10)$ \\
LEV (leverage) & $(2.61)$ & & & 0.0054 \\
& 0.0012 & -0.0102 & -0.0013 & $(0.29)$ \\
COMP (CEO compensation) & $(0.07)$ & $(-0.56)$ & $(-0.07)$ & 0.0028 \\
& 0.0017 & 0.0030 & 0.0027 & $(1.47)$ \\
LASSET (firm size) & $(0.91)$ & $(1.56)$ & $(1.39)$ & $-0.0144^{* * *}$ \\
CONSTANT & $-0.0094^{* *}$ & $-0.0118^{* * * *}$ & $-0.0121^{* * *}$ & $(-4.22)$ \\
R-squared & $(-2.46)$ & $(-3.20)$ & $(-3.19)$ & $0.1855^{* * *}$ \\
F-test & $0.1419^{* *}$ & $0.1418^{* *}$ & $0.2027^{* * *}$ & $(3.30)$ \\
\hline & $(2.32)$ & $(2.39)$ & $(3.57)$ & 0.1423 \\
& 0.2204 & 0.1590 & 0.0832 & $32.13^{* * *}$ \\
\hline
\end{tabular}

Note: $z$-statistics in parentheses. ${ }^{* * *},{ }^{* *}$ and ${ }^{*}=$ significant at 1 percent, 5 percent, and 10 percent level, respectively.

Source: Authors' calculations. 
We find that audit committee independence is negatively related to the use of discretionary accruals, allowing us to accept the sixth hypothesis. The presence of outside members on the committee strengthens its effective oversight, thus reducing the likelihood of corporate failure and financial fraud. Based on the first and fourth columns of Table 4, we reject the seventh hypothesis because insider shareholding does not appear to be positively related to earnings management.

We accept the eighth hypothesis because the results indicate that institutional shareholding is positively related to the use of discretionary accruals. This finding is consistent with Bushee (1998), Matsumoto (2002), Koh (2003), and Cornett et al. (2006), who find a positive association between institutional shareholding and income-increasing discretionary accruals. The rationale for this lies in Matsumoto (2002), who argues that institutional investors induce managers to engage in earnings management in order to avoid surprise negative earnings and deliver higher consistent earnings instead.

Finally, leverage and CEO compensation are not related to earnings management, but the results reveal a negative relationship between firm size and the use of discretionary accruals. This finding supports the argument that large firms are subject to greater scrutiny and, therefore, less likely to be involved in earnings management. Columns 1 to 4 (Table 4) show that the independent and control variables have almost the same relationship with earnings management.

The study's second objective is to investigate whether the role of corporate governance in constraining earnings management differs between high-growth and low-growth firms. For this, we divide the data into high- and low-growth firms. Following Mitton (2002), all firms below the median BM ratio are treated as high-growth firms while all those above the median BM ratio are treated as low-growth firms. Table 5 gives separate regression estimates for high- and low-growth firms.

The results reveal significant differences in how governance mechanisms constrain earnings management in high- and low-growth firms. CEO duality is positively related to earnings management in highgrowth firms. Given that such firms have larger operations and accounting records, and are likely more diversified, CEO duality would imply that the CEO controls a significant volume of information. 
The results also indicate that the more independent a firm's audit committee, the less likely will be the use of discretionary accruals; this applies to both high-growth as well as low-growth firms. Outside members on the audit committee are independent from the firm's management and, therefore, can better influence managerial discretion. The frequency of board meetings in the case of low-growth firms is related to lower levels of earnings management, where a more active board is likely to play an important role in monitoring management. While the full sample data regression (Table 4) shows that institutional shareholding is positively associated with earnings management, the separate regression results give a different picture. Table 5 shows that institutional shareholding is not related to earnings management in highgrowth firms. Only in low-growth firms are transient institutional investors able to induce managers toward earnings management.

Table 5: High- and low-growth firms: Sample regression estimates

\begin{tabular}{lcc} 
& \multicolumn{2}{c}{ Dependent variable = discretionary accruals } \\
\hline & \multicolumn{2}{c}{ z-statistics } \\
\cline { 2 - 3 } Variable & High-growth firms & Low-growth firms \\
\hline IBOARD (board independence) & -0.0056 & -0.0304 \\
CEO (CEO duality) & $(-0.19)$ & $(-1.13)$ \\
& $0.0997^{* * *}$ & 0.0152 \\
SBOARD (board size) & $(4.57)$ & $(0.92)$ \\
MBOARD (board meetings) & 0.0065 & -0.0009 \\
SAC (size of audit committee) & $(1.27)$ & $(-0.14)$ \\
IAC (audit committee independence) & -0.0172 & $-0.0459^{*}$ \\
POI (insider shareholding) & $(-0.91)$ & $(-1.89)$ \\
& -0.0096 & 0.0177 \\
POINST (institutional shareholding) & $(-0.90)$ & $(1.37)$ \\
& $-0.0813^{* *}$ & $-0.0558^{*}$ \\
LEV (leverage) & $(-2.51)$ & $(-1.73)$ \\
COMP (CEO compensation) & -0.0500 & -0.0172 \\
F-test & $(-1.15)$ & $(-0.48)$ \\
\hline
\end{tabular}

Note: ${ }^{* * *}{ }^{* *}$ and ${ }^{*}=$ significant at 1 percent, 5 percent and 10 percent level, respectively. Source: Authors' calculations. 


\section{Conclusion}

The first objective of this study was to investigate the effect of corporate governance in constraining earnings management. Based on the comparative predictive powers of the Jones model, modified Jones model, and augmented Jones model, we have used the third option to estimate discretionary accruals. The results show that audit committee independence is an effective corporate governance mechanism in constraining earnings management practices. Moreover, such practices increase with CEO duality and greater institutional equity shareholding.

Additionally, we find that the effectiveness of corporate governance mechanisms differs for high-growth and low-growth firms. These results have important implications for constraining earnings management practices. CEO duality, for instance, is positively related to earnings management only in the case of high-growth firms. This implies that CEOs that also chair a firm's board may become heavily involved in earnings management to ensure that the firm remains attractive; this is not the case for low-growth firms. Institutional shareholding is positively related to earnings management only for low-growth firms and is irrelevant in the case of high-growth firms. The independence of the audit committee is negatively associated with the practice of earnings management for both high-growth and low-growth firms. Thus, an independent audit committee is likely to prove an effective corporate governance mechanism and ensure that financial reports remain neutral.

These results suggest that, in the first instance, the board should formulate procedures to ensure that it has access to a range of information. Second, the audit committee should make certain that the firm's financial statements comply with financial reporting standards. Third, the board should establish an internal audit function to review the firm's risk management, internal auditing, and effectiveness of governance and report on these to the audit committee.

One possible avenue for further research is to examine additional governance attributes such as the age and qualifications of board members and the CEO, the size of the compensation committee, the attendance rate of board meetings, and the knowledge and expertise of board and audit committee members. Based on the new code of corporate governance issued by the Securities and Exchange Commission of Pakistan in 2012, another avenue for research could be to determine whether the effectiveness of corporate governance mechanisms has 
improved following the implementation of the new code. Finally, although earlier research suggests that insider shareholding and institutional shareholding reduce earnings management, this study has not found any such evidence. This makes it necessary to examine additional variables such as the interaction between corporate governance attributes and insider shareholding in the presence of longterm institutional investors on the board. 


\section{References}

Abbott, L. J., Parker, S., \& Peters, G. F. (2004). Audit committee characteristics and restatements. Auditing: Journal of Practice and Theory, 23(1), 69-89.

Abed, S., Al-Attar, A., \& Suwaidan, M. (2012). Corporate governance and earnings management: Jordanian evidence. International Business Research, 5(1), 216-225.

Almilia, L. S. (2009). Determining factors of Internet financial reporting in Indonesia. Accounting and Taxation, 1(1), 87-99.

Alzoubi, E. S. S., \& Selamat, M. H. (2012). The effectiveness of corporate governance mechanisms on constraining earning management: Literature review and proposed framework. International Journal of Global Business, 5(1), 17-35.

Bartov, E., Gul, F. A., \& Tsui, J. S. L. (2000). Discretionary-accruals models and audit qualifications. Journal of Accounting and Economics, 30(3), 421-452.

Beneish, M. D., \& Vargus, M. E. (2002). Insider trading, earnings quality, and accrual mispricing. The Accounting Review, 77(4), 755-791.

Bowen, R. M., Rajgopal, S., \& Venkatachalam, M. (2008). Accounting discretion, corporate governance, and firm performance. Contemporary Accounting Research, 25(2), 351-405.

Bushee, B. (1998). The influence of institutional investors on myopic R\&D investment behavior. The Accounting Review, 73(3), 305-333.

Chen, G., Firth, M., Gao, D. N., \& Rui, O. M. (2006). Ownership structure, corporate governance, and fraud: Evidence from China. Journal of Corporate Finance, 12(3), 424-448.

Cohen, D. A., Dey, A., \& Lys, T. Z. (2004). Trends in earnings management and informativeness of earnings announcements in the pre- and postSarbanes Oxley periods. Unpublished manuscript. Retrieved from (http:/ /apps.olin.wustl.edu/jfi/pdf/CohenDeyLys.pdf). 
Cohen, J. R., Krishnamoorthy, G., \& Wright, A. (2004). The corporate governance mosaic and financial reporting quality. Journal of Accounting Literature, 23, 87-152.

Cornett, M. M., Marcus, A. J., Saunders, A., \& Tehranian, H. (2006). Earnings management, corporate governance, and true financial performance. Unpublished manuscript. Retrieved from (http://www.researchgate.net/profile/Hassan_Tehranian/publicati on/228238263_Earnings_Management_Corporate_Governance_and _True_Financial_Performance/links/0c960535f9236ee94f000000.pdf).

Davidson, W. N., Jiraporn, P., Kim, Y. S., \& Nemec, C. (2004). Earnings management following duality-creating successions: Ethnostatistics, impression management, and agency theory. Academy of Management Journal, 47(2), 267-275.

Dechow, P., Sloan, R., \& Sweeney, A. (1996). Causes and consequences of earnings manipulation: An analysis of firms subject to enforcement actions by the SEC. Contemporary Accounting Research, 13(1), 1-36.

DeFond, M. L., \& Jiambalvo, J. (1994). Debt covenant violation and manipulation of accruals. Journal of Accounting and Economics, 17(1-2), 145-176.

Dimitropoulos, P. E., \& Asteriou, D. (2010). The effect of board composition on the informativeness and quality of annual earnings: Empirical evidence from Greece. Research in International Business and Finance, 24(2), 190-205.

González, J. S., \& García-Meca, E. (2014). Does corporate governance influence earnings management in Latin American markets? Journal of Business Ethics, 121(3), 419-440.

Hartzell, J. C., \& Starks, L. T. (2003). Institutional investors and executive compensation. Journal of Finance, 58(6), 2351-2374.

Healy, P. M., \& Wahlen, J. M. (1999). A review of the earnings management literature and its implications for standard setting. Accounting Horizons, 13(4), 365-383. 
Hribar, P., \& Collins, D. W. (2002). Errors in estimating accruals: Implications for empirical research. Journal of Accounting Research, 40(1), 105-134.

Islam, M. A., Ali, R., \& Ahmad, Z. (2011). Is modified Jones model effective in detecting earnings management? Evidence from a developing economy. International Journal of Economics and Finance, $3(2), 116-125$.

Jensen, M. C. (1993). The modern industrial revolution, exit, and the failure of internal control systems. Journal of Finance, 48(3), 831-880.

Jensen, M. C., \& Meckling, W. H. (1976). Theory of the firm: Managerial behavior, agency costs and ownership structure. Journal of Financial Economics, 3(4), 305-360.

Jiang, W., Lee, P., \& Anandarajan, A. (2008). The association between corporate governance and earnings quality: Further evidence using the GOV-score. Advances in Accounting, 24(2), 191-201.

Klein, A. (2002). Audit committee, board of director characteristics, and earnings management. Journal of Accounting and Economics, 33(3), 375-400.

Koh, P.-S. (2003). On the association between institutional ownership and aggressive corporate earnings management in Australia. British Accounting Review, 35(2), 105-128.

Mansor, N., Che-Ahmad, A., Ahmad-Zaluki, N. A., \& Osman, A. H. (2013). Corporate governance and earnings management: A study on the Malaysian family- and nonfamily-owned PLCs. Procedia Economics and Finance, 7, 221-229.

Matsumoto, D. A. (2002). Management's incentives to avoid negative earnings surprises. The Accounting Review, 77(3), 483-514.

McKee, T. E. (2005). Earnings management: An executive perspective. Mason, $\mathrm{OH}$ : Thomson.

McNichols, M. F. (2000). Research design issues in earnings management studies. Journal of Accounting and Public Policy, 19(4-5), 313-345. 
Mitton, T. (2002). A cross-firm analysis of the impact of corporate governance on the East Asian financial crisis. Journal of Financial Economics, 64(2), 215-241.

Peasnell, K. V., Pope, P. F., \& Young, S. (2005). Board monitoring and earnings management: Do outside directors influence abnormal accruals? Journal of Business Finance and Accounting, 32(7-8), 13111346.

Standard \& Poor's. (2003). Transparency and disclosure study. New York, NY: McGraw-Hill.

Waweru, N. M., \& Riro, G. K. (2013). Corporate governance, firm characteristics and earnings management in an emerging economy. Journal of Applied Management Accounting Research, 11(1), $43-64$.

Zhang, Y., Shi, C., Gao, P., \& Wang, F. (2014). Repealing the LIFO inventory accounting choice? A review of LIFO and inventory management. American Journal of Operations Research, 4(6), 351-364. 